\title{
Russefeiring og eksamenstid - bruk av fastlege og legevakt
}

\begin{abstract}
BAKGRUNN Økt forbruk av antibiotika og høyere skadefrekvens for 19-åringer i mai er beskrevet tidligere. Vi undersøkte om 19-åringene også hadde økt forbruk av allmennlegetjenester $\mathrm{i}$ tiden omkring russefeiringen.
\end{abstract}

MATERIALE OG METODE Studien er basert på data fra Helsedirektoratets system for kontroll og utbetaling av helserefusjon (KUHR) om alle konsultasjoner i allmennlegetjenesten for aldersgruppen 18-20 år for årene 2012-15. Antall konsultasjoner per måned og aldersgruppe ble analysert med Poisson-regresjon med 19-åringer i mars som referansegruppe. Insidensrateratio (IRR) var effektmål.

RESULTATER I alle kalenderår var det sterk økning i antall konsultasjoner blant 19-åringer i mai sammenlignet med andre kalendermåneder og med årskullene over og under. For fastlege- og legevaktkonsultasjoner var insidensrateratio henholdsvis 1,40 (95\% konfidensintervall (KI) 1,38-1,41) og 2,07 (95\% KI 2,02-2,13). Økningen var sterkest for luftveisinfeksjon (IRR 3,64, 95\% KI 3,55-3,73). Insidensrateratio for skader var 1,21 (95\% KI 1,16-1,27). $\emptyset$ kningen startet de tre siste ukene før 17. mai og vedvarte de to første ukene etter nasjonaldagen.

FORTOLKNING Den sterke økningen i konsultasjoner i allmennlegetjenesten for 19-åringer i mai er nær knyttet i tid til russefeiringen. Den økte kontakten med allmennlegetjenesten vedvarte inn i den påfølgende eksamensperioden.

I Norge har alle med fullført grunnskole lovfestet rett til tilbud om heltids treårig videregående opplæring. De fleste unge benytter seg av dette tilbudet, og i 2015 var over $90 \%$ av alle $\mathrm{i}$ alderen 16-18 år i videregående opplæring (1).

Russetiden som feiring av fullført videregående skole har lange tradisjoner i Norge. Etter vanlig forløp er man russ det året man fyller 19 år. Selv om ikke mer enn $73 \%$ av dem som startet et videregående utdanningsløp hadde fullført etter fem år (1), deltar svært mange ungdommer i russefeiringen det året de fyller 19 år. For mange består russetiden av flere ukers feiring som i stor grad foregår utendørs og er preget av et høyt konsum av alkohol (2) - noe som kan gi økt risiko for sykdom og skade. Russefeiringen er mest intens i ukene like før Norges nasjonaldag 17. mai. De påfølgende ukene er eksamensperiode for avgangselevene, vanligvis med oppstart 19. mai (3). Eksamenskarakterene kommer i tillegg til standpunktkarakterene og teller med når elevene skal søke opptak til høyere utdanning.

Tidligere studier har vist økt forekomst av skader behandlet i spesialisthelsetjenesten (4) og økt forbruk av antibiotika og hostemedisin (5) blant 19-åringer i mai. Det er også rapportert om utbrudd av meningokokkinfeksjoner blant russ (6). Utover dette er det lite kunnskap om russens helsetilstand og helsetjenestebruk.

I denne studien undersøkte vi 19-åringenes bruk av allmennlegetjenester i forbindelse med russetiden. Vi sammenlignet bruken i ma måned med bruken $\mathrm{i}$ årets øvrige måneder og 19-åringer med ungdommer som var ett år eldre eller eller ett år yngre. Vi analyserte konsultasjoner hos fastlege og legevakt og så nærmere på noen utvalgte diagnosegrupper.

\section{Materiale og metode}

Studien er basert på data fra Helsedirektoratets system for kontroll og utbetaling av helserefusjon (KUHR), som inneholder informasjon om alle pasientkontakter hos fastleger og på legevakt. Befolkningsgrunnlaget per 1. januar for årene 2012-15 er hentet fra Statistisk sentralbyrås nettsider (7). Dataene hadde ingen personentydige kjennetegn og studien var derfor ikke fremleggelsespliktig for regional etisk komité.

Datagrunnlaget var refusjonskrav fra allmennlegetjenesten fra en periode på fire år (2012-15) for årskullene som fylte 18-20 år innenfor hvert av de aktuelle kalenderårene. Datasettet inneholdt informasjon om fødselsår og kjønn, konsultasjonsdato, diagnosekoder i henhold til International Classification of Primary Care 2 (ICPC-2), takstkoder og praksistype (legevakt/fastlege). Vi inkluderte konsultasjoner med takstkodene 2ad (konsultasjon hos allmennpraktiserende lege på dagtid), 2ak (konsultasjon hos allmennpraktiserende lege på kveld, natt og helgedag) og $2 \mathrm{fk}$ (konsultasjon og tillegg for utrykning til kontor ved øyeblikkelig hjelp under legevakt) (8). Telefonkontakter og sykebesøk ble ikke inkludert.
Inger Johanne Bakken

inger.johanne.bakken@fhi.no

Folkehelseinstituttet

Knut-Arne Wensaas

Allmennmedisinsk forskningsenhet

Uni Research Helse

og

Institutt for global helse og samfunnsmedisin Universitetet i Bergen

Gry Marysol Grøneng

Folkehelseinstituttet

\section{Atle Fretheim}

Folkehelseinstituttet

Camilla Stoltenberg

Folkehelseinstituttet

og

Institutt for global helse og samfunnsmedisin Universitetet i Bergen

\section{Knut Inge Klepp}

Folkehelseinstituttet

Siri Eldevik Håberg

Folkehelseinstituttet

Simon Øverland

Folkehelseinstituttet

og

Institutt for samfunnspsykologi

Universitetet i Bergen

e-tab 1, e-tab 2, e-fig 3 og e-fig 4 finnes

i Tidsskriftets elektroniske utgaver

ID

Engelsk oversettelse på www.tidsskriftet.no

Publisert først på nett

\section{HOVEDBUDSKAP}

I mai måned i 2015 hadde 19-åringer 19891 konsultasjoner i allmennlegetjenesten, mens tilsvarende tall var 11627 for 18-åringer og 12200 for 20-åringer

Luftveisinfeksjoner sto for det meste av økningen, men også skader og ulykker bidro

Mønsteret var det samme for alle årene i perioden 2012-15 

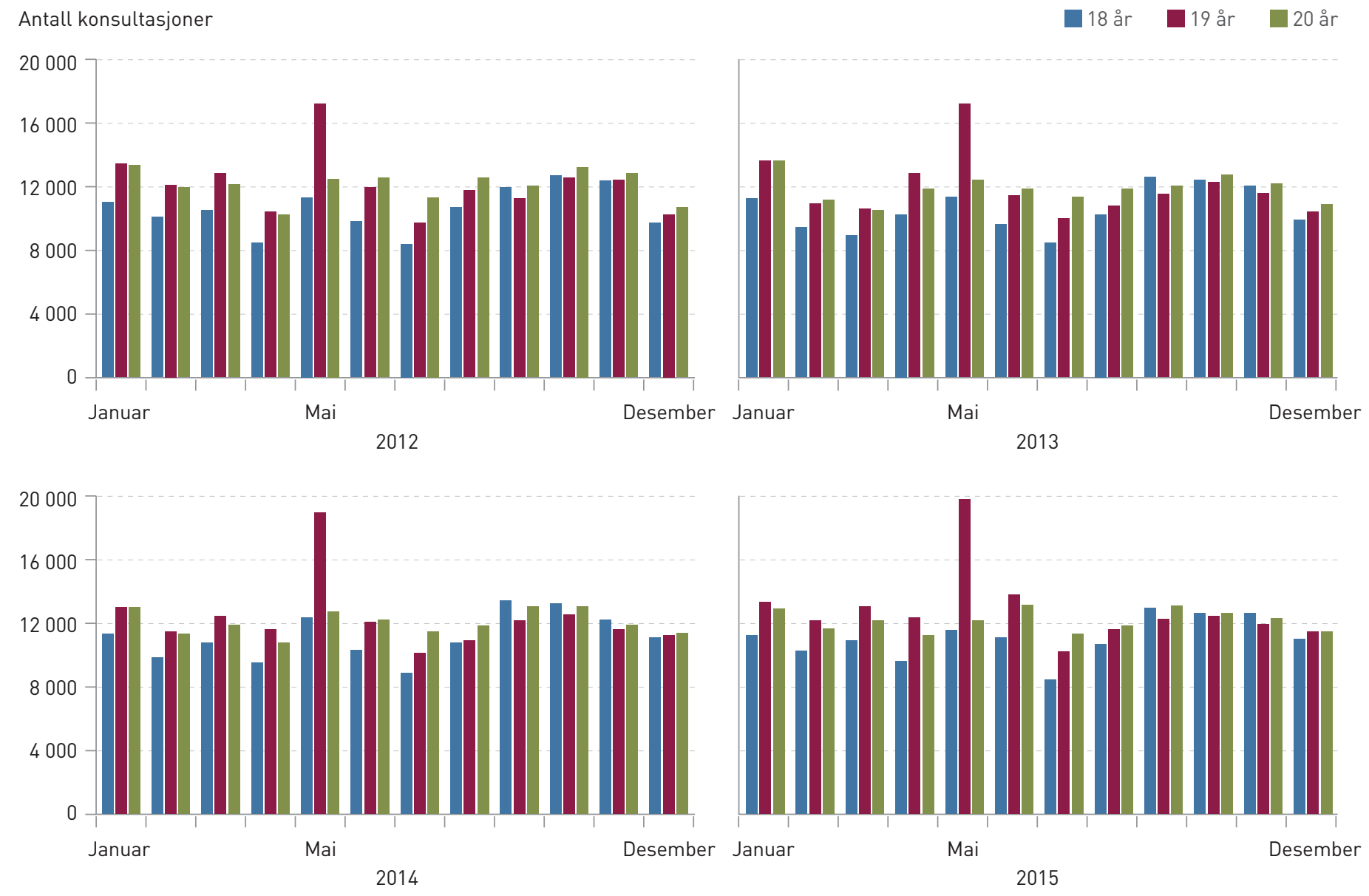

Figur 1 Antall konsultasjoner totalt hos fastlege og i legevakt per kalendermåned for 18-20-åringer i årene 2012-15

Vi beregnet alder ved å trekke fødselsår fra kalenderår. Vi bruker begrepet «19-åringer» om alle som fylte 19 år innenfor et aktuelt kalenderår, uavhengig av når på året de var født. Vi kategoriserte 18- og 20-åringer på samme måte. I det norske skolesystemet starter barna på skolen det året de fyller seks år, og med normal progresjon vil 19-åringer etter vår definisjon utgjøre «russekullet».

Ved de fleste konsultasjonene $(87,2 \%)$ var det bare registrert én diagnose. Vi tok hensyn til alle registrerte koder da vi grupperte diagnosene i seks ulike hovedkategorier: luftveisinfeksjoner, smerter og muskelplager, psykisk lidelse, ulykker og skader, mage- og tarmplager, og andre tilstander (e-tab 1). I tillegg undersøkte vi hver enkelt ICPC-2-kode separat innenfor den største gruppen (luftveisinfeksjoner). Grupperingen er basert på Statistisk sentralbyrås inndeling (9).

\section{Statistiske analyser}

Alle analyser er utført ved hjelp av programpakken Stata ${ }^{14}$ (Statacorp, Texas). Vi fremstilte antall konsultasjoner per kalendermåned etter årskull og år grafisk. I tillegg benyttet vi Poisson-regresjonsmodeller med antall konsultasjoner per måned som utfallsvariabel og ulike kombinasjoner av år, måned, kjønn og årskull som forklaringsvariabler. I Poisson-regresjonen tok vi hensyn til antall i befolkningen i de ulike kategoriene og antall dager i den aktuelle måneden.

Resultatene er fremstilt som insidensrateratio (IRR) med $95 \%$ konfidensintervall (KI) med data for 19-åringer i mars som referanse. Insidensrateratio gir her dermed et mål for antall konsultasjoner for et gitt årskull i en gitt kalendermåned sett $\mathrm{i}$ forhold til antall konsultasjoner for 19-åringer i mars.

Vi valgte 19-åringer som referansekategori for å unngå at eventuelle forskjeller i legesøkning basert på alder snarere enn kalendermåned skulle påvirke resultatene. Mars ble valgt fordi denne måneden er nærmeste skolemåned utenfor den mest intense russefeiringen, samtidig som det ikke er feriemåned. For å se nærmere på effekter av tid fremstilte vi også antall konsultasjoner per uke etter årskull og år grafisk.

\section{Resultater}

Det var registrert i alt 1690139 konsultasjoner for 18-20-åringer i perioden 2012-15.
Det årlige antall konsultasjoner økte fra 417322 i 2012 til 434524 i 2015 (en økning på $4,1 \%$ ), samtidig som befolkningsgrunnlaget økte fra 197099 til 199689 (en økning på $1,3 \%)$.

Det totale antallet konsultasjoner i mai for 19-åringene var høyere enn i andre måneder, og høyere enn for yngre og eldre årskull i mai måned i alle de fire årene i studieperioden (fig 1). I mai måned 2015 var det registrert 19891 konsultasjoner totalt for 19åringene, mens tilsvarende antall for dem som var ett år yngre og ett år eldre var henholdsvis 11627 og 12200 (fig 1). For andre kalendermåneder var det liten forskjell mellom de aktuelle årskullene.

E-tabell 2 viser månedsvis antall konsultasjoner per 1000 innbyggere etter årskull hos fastlege, på legevakt og for hver diagnosegruppe for året 2015. Tabellen viser at det er en markert økning både i antall fastlegekonsultasjoner og i antall legevaktbesøk for 19-åringene i mai, sammenlignet med 19åringene $\mathrm{i}$ andre måneder og med årskullene som var ett år yngre og ett år eldre samme måned. Økningen var mest markert for diagnosegruppen luftveisinfeksjoner. For dia- 
gnosegruppen ulykker og skader fant vi også høyere antall konsultasjoner for 19-åringene enn for 18- og 20-åringene i mai, men her var det totale volumet av konsultasjoner betydelig mindre. Fordelingene og forskjellene fulgte et tilsvarende mønster for årene 2012-14 (data ikke vist).

For hele perioden 2012-15 under ett ga sammenligningen av antall konsultasjoner hos fastlege for 19-åringer i mai med antall konsultasjoner for 19-åringer i mars en insidensrateratio på 1,40 (95\% KI 1,38-1,41) (fig 2). For konsultasjoner på legevakt var det en fordobling for 19-åringer i mai sammenlignet med 19-åringer i mars (IRR 2,07, $95 \%$ KI 2,02-2,13). 18-åringene hadde også litt høyere forekomst av legevaktbesøk i mai enn 19-åringer i mars, men denne forskjellen var langt mindre enn tilsvarende forskjell mellom månedene for 19-åringene (fig 2).

Av diagnosegruppene skilte luftveisinfeksjoner seg klart ut - med sterkest økning i antall konsultasjoner i mai for 19-åringene (IRR 3,64, 95\% KI 3,55-3,73 sammenlignet med 19-åringene i mars). For 18-åringene var det også flere konsultasjoner i mai enn for 19-åringene i mars, men forskjellen var på langt nær like stor. Antallet konsultasjoner innenfor diagnosegruppen ulykker og skader var også høyere blant 19-åringene i mai (IRR 1,21, $95 \%$ KI 1,16-1,27), mens antallet konsultasjoner med diagnosene smerter, psykiske lidelser og mage- og tarmplager var litt lavere i mai enn i mars for 19åringene.

Vi gjorde tilsvarende analyser for hver diagnosekode innenfor diagnosegruppen luftveisinfeksjoner. Mønsteret med økning i mai for 19-åringene var tydelig for alle kodene, med unntak av R80 influensa, som viste et typisk sesongmønster med flere konsultasjoner i vintermånedene (ikke vist). Det største volumet av konsultasjoner var for diagnosen R74 akutt øvre luftveisinfeksjon (e-fig 3). For denne diagnosen var insidensrateratio for 19-åringer i mai sammenlignet med 19-åringer i mars på 4,41 $(95 \% \mathrm{KI}$ 4,22-4,60).

E-figur 4 viser antall konsultasjoner totalt, antall konsultasjoner med akutt øvre luftveisinfeksjon og antall konsultasjoner med skadediagnose for hver uke fra mars til oktober 2015. For 19-åringene var det økning i totalantallet konsultasjoner i ukene 19 og 20 (perioden 6.-17. mai), sterk økt antall konsultasjoner i uke 21 (18.-24. mai), med en påfølgende nedgang (e-fig 4a). Konsultasjoner for akutt øvre luftveisinfeksjon fulgte samme mønster (e-fig 4b). Det meste av økningen i skadediagnoser for 19-åringene kom i ukene frem mot 17. mai, med en brå nedgang rett etter nasjonaldagen. Volumet av konsultasjoner for skader og ulykker var

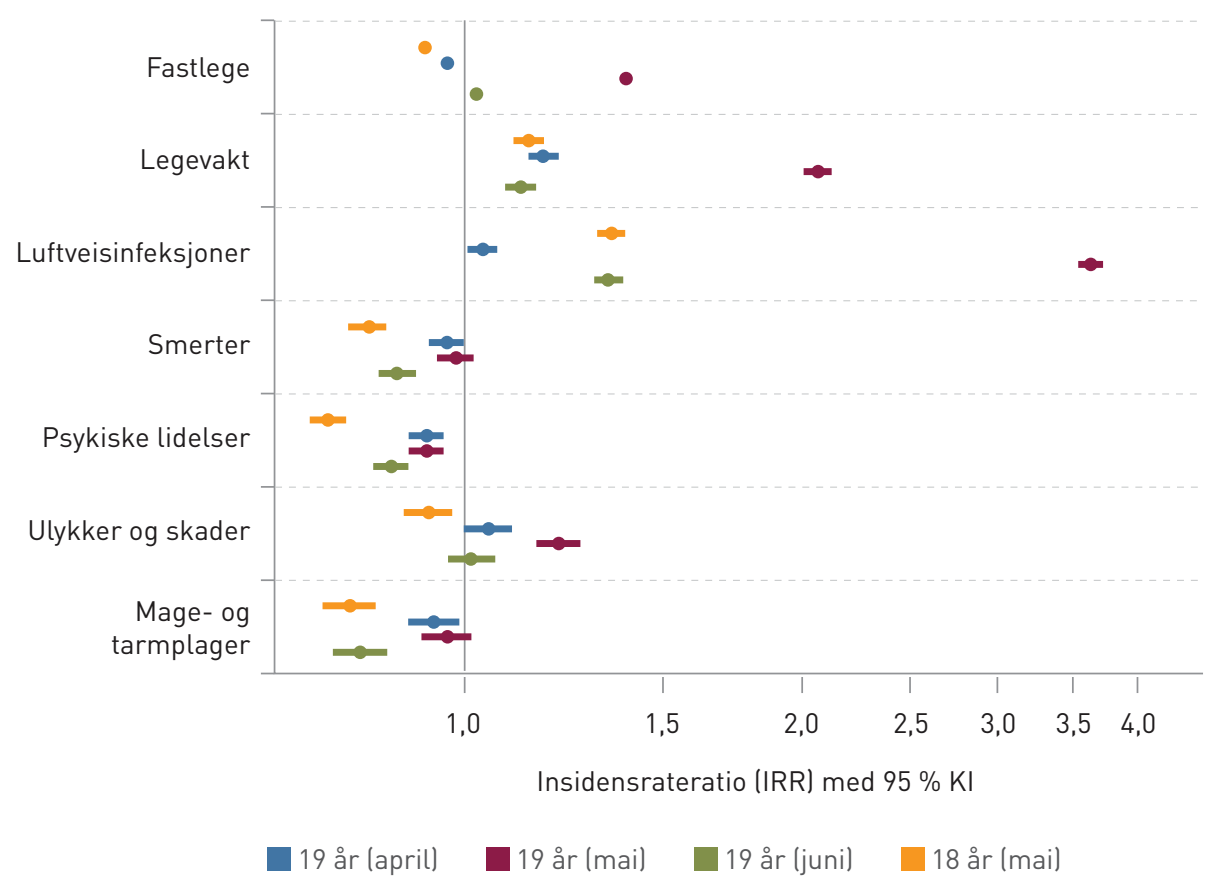

Figur 2 Insidensrateratio (IRR) med $95 \%$ konfidensintervall llogaritmisk skala) for konsultasjoner i april, mai og juni for 19-åringer og i mai for 18-åringer (data 2012-15). Referansegruppen er 19-åringer i mars

imidlertid lavt i forhold til infeksjonsdiagnosene (e-fig 4c).

\section{Diskusjon}

I alle år fra 2012 til 2015 var antallet konsultasjoner hos fastleger og på legevakt høyere i mai enn $i$ alle andre kalendermåneder for 19-åringene. For andre årskull ble det ikke observert noe slikt mønster, og for andre kalendermåneder enn mai var det ikke særlig stor forskjell mellom 19-åringene og årskullene under og over. For enkeltdiagnosen akutt øvre luftveisinfeksjon var det nesten fire ganger så mange konsultasjoner i mai for 19-åringene som $\mathrm{i}$ mars. Vi fant videre at antallet konsultasjoner for 19-åringene var høyt både i første og andre halvdel av mai for totalantallet konsultasjoner og for enkeltdiagnosen akutt øvre luftveisinfeksjon. For skader observerte vi imidlertid bare økning i første halvdel av mai.

Datagrunnlaget i denne studien er Helsedirektoratets databaser over statlige helserefusjoner til fastleger og legevakt - KUHR. Dette datagrunnlaget er ikke organisert som et helseregister. Det er en styrke at KUHRdatabasen er tilnærmet komplett, i den forstand at den inneholder data fra samtlige konsultasjoner som det kreves refusjon for fra norsk allmennlegetjeneste.

Det er lite kunnskap om diagnosekvaliteten, men vi antar at den varierer mellom diagnosene. En studie fra kanadisk allmennpraksis har vist god datakvalitet for diagnosene epilepsi, parkinsonisme og demens, men mer moderate resultater for kronisk obstruktiv lungesykdom og depresjon (10). En tidligere norsk studie (data fra 1992-2008) har vist at det ofte ikke ble brukt korrekte koder i innrapporteringen (11). I vår studie er noe av usikkerheten redusert ved at vi har kombinert diagnosekoder til store diagnosegrupper. Helsestasjon for ungdom inngår ikke i datagrunnlaget, og vi har derfor ikke fanget opp all kontakt som i stor grad vil kunne gjelde seksuell helse og lettere psykiske plager.

Tidligere studier fra Folkehelseinstituttet har vist økning i antibiotikabruk (5) og antall skader behandlet i spesialisthelsetjenesten (4) i mai måned for 19-åringer. Vi antar at en stor andel av økningen i antibiotikabruk og skader, og også økningen som vi nå observerer $i$ antallet konsultasjoner $i$ allmennlegetjenesten, kan knyttes til russetiden. Antallet konsultasjoner var økt for russekullet i første halvdel av mai, før eksamensperioden startet.

For de fleste som har deltatt i russefeiringen, er mai imidlertid også tid for eksamen. Eksamenskarakterene er viktige for videre kvalifikasjon til høyere utdanning og arbeid, og sykdom under eksamen som dokumenteres med legeerklæring, gir rett til ny eksamen senere (12). Den kraftige økningen i bruken av allmennlegetjenesten også i siste halvdel av mai kan antagelig til en viss grad forklares med et behov for behandling for infeksjoner i eksamenstiden eller for å dokumentere sykdom for å sikre eksamensrettigheter. Datagrunnlaget gir imidlertid ikke 
mulighet til å analysere forekomst av legeerklæring knyttet til eksamensfritak.

Den relative økningen i konsultasjoner i mai blant 19-åringer var størst når det gjelder legevaktbesøk, men i antall var økningen størst hos fastlegene. Dette sammenfaller med funnene $i$ en studie fra influensapandemien $i$ 2009, hvor forfatterne konkluderte med at allmennlegetjenesten var fleksibel og kunne respondere ved økt behov i befolkningen (13)

Feiringen i forkant av en viktig eksamensperiode er, etter hva vi kjenner til, en særnorsk tradisjon. Tilsvarende feiringer blant ungdom og unge voksne er $\mathrm{i}$ andre land oftere knyttet til oppstart av utdanning eller er lagt til ferieperioder $(14,15)$. Fadderukearrangementene ved norske universiteter og høyskoler foregår ved oppstart av studiene og er ansett for å være mindre omfattende enn russefeiringen $(16,17)$.

$\AA$ flytte russefeiringen til etter eksamensperioden, alternativt å flytte eksamensperioden frem til før russetiden, har vært foreslått flere ganger, og i fjor ble det satt ned et nytt utvalg som skal se på omorganisering av skoleåret (18).

\section{Konklusjon}

Årskullet som avslutter videregående opplæring hadde i alle årene et betydelig større antall konsultasjoner $i$ allmennlegetjenesten i mai måned enn årskullet under og over. Den hyppigste årsaken var luftveisinfeksjoner. Økningen startet i perioden før 17. mai og vedvarte inn i eksamensperioden.

Økningen i behov for legetjenester kan sannsynligvis forklares med en kombinasjon av økt forekomst av luftveisinfeksjoner i russetiden og et $ø \mathrm{kt}$ behov for behandling og legeerklæringer i eksamensperioden.

\section{Inger Johanne Bakken (f. 1968)}

er dr.ing. i biofysikk og medisinsk teknologi og seniorrådgiver.

Forfatter har fylt ut ICMJE-skjemaet og oppgir ingen interessekonflikter.

\section{Knut-Arne Wensaas (f. 1964)}

er postdoktor, førsteamanuensis II, spesialist i allmennmedisin og fastlege.

Forfatter har fylt ut ICMJE-skjemaet og oppgir ingen interessekonflikter.

\section{Gry Marysol Grøneng (f. 1978)}

er veterinær og ph.d. i epidemiologi. Hun er seniorrådgiver og prosjektleder for overvåkningssystemet Sykdomspulsen.

Forfatter har fylt ut ICMJE-skjemaet og oppgir ingen interessekonflikter.

\section{Atle Fretheim (f. 1968)}

er lege og forskningsleder og professor II ved Universitetet i Oslo.

Forfatter har fylt ut ICMJE-skjemaet og oppgir ingen interessekonflikter.

\section{Camilla Stoltenberg (f. 1958)}

er lege, dr.med. i epidemiologi og direktør og professor II ved Universitetet i Bergen.

Forfatter har fylt ut ICMJE-skjemaet og oppgir ingen interessekonflikter

\section{Knut Inge Klepp (f. 1955)}

har en mastergrad i folkehelse og en ph.d.grad i epidemiologi og er områdedirektør. Han er professor II ved Universitetet i Oslo.

Forfatter har fylt ut ICMJE-skjemaet og oppgir ingen interessekonflikter.

\section{Siri Eldevik Håberg (f. 1969)}

er lege, har en ph.d.-grad i epidemiologi og er fagdirektør.

Forfatter har fylt ut ICMJE-skjemaet og oppgir ingen interessekonflikter.

\section{Simon Øverland (f. 1975)}

er psykolog og fagdirektør og professor II ved Universitetet i Bergen.

Forfatter har fylt ut ICMJE-skjemaet og oppgir ingen interessekonflikter

\section{Litteratur}

1. Statistisk sentralbyrå. Nøkkeltall for utdanning http://www.ssb.no/utdanning/nokkeltall/ utdanning (3.4.2017).

2. Fjaer EG, Pedersen W, Sandberg S. Party on wheels: mobile party spaces in the Norwegian high school graduation celebration. $\mathrm{Br} J$ Sociol 2016; 67: 328-47

3. Utdanningsdirektoratet. Kalender. https://www.udir.no/Kalender/Eksamen-ogprover/ (3.4.2017)

4. Austdal LE, Strand MC, Vindenes V et al. Forekomst av skader i russetiden. Tidsskr Nor Legeforen 2015: 135: 648-52.

5. Blix HS, Hjellvik V. Økt bruk av antibiotika blant 19-åringer i mai. Tidsskr Nor Legeforen 2012; 132 1084-8.

6. Folkehelseinsituttet. Ungdom bør vurdere å vaksinere seg mot smittsom hjernehinnebetennelse. https://www.fhi.no/sv/smittsomme-sykdommer/ hjernehinnebetennelse/ungdom-bor-vurderea-vaksinere-seg-mot-smittsomhjernehinnebetennelse/ (3.4.2017)

7. Statistisk sentralbyrå. Tabell 07459: Folkemengde etter kjønn og ettårig alder. https://www.ssb.no/ statistikkbanken/ [3.4.2017).

8. Den norske legeforening. Normaltariffen. http://normaltariffen.legeforeningen.no/ (3.4.2017)

9. Statistisk sentralbyrå. Allmennlegetjenesten, 2012. https://www.ssb.no/helse/statistikker/ fastlegetj/aar/2013-09-18 (3.4.2017).

10. Williamson T, Green ME, Birtwhistle R et al. Validating the 8 CPCSSN case definitions for chronic disease surveillance in a primary care database of electronic health records. Ann Fam Med 2014; 12: $367-72$

11. Botsis T, Bassøe C-F, Hartvigsen G. Sixteen years of ICPC use in Norwegian primary care: looking through the facts. BMC Med Inform Decis Mak 2010; 10: 11

12. Lovdata. Forskrift til opplæringslova. Kap. 4-5 § 3-35. https://lovdata.no/dokument/SF/forskrift/ 2006-06-23-724 (14.2.2017)

13. Simonsen KA, Hunskaar S, Sandvik H et al. Capacity and adaptations of general practice during an influenza pandemic. PLoS One 2013. 8. e69408.

14. Campo S, Poulos G, Sipple JW. Prevalence and profiling: hazing among college students and points of intervention. Am J Health Behav 2005; 29: $137-49$

15. Riordan BC, Scarf D, Conner TS. Is orientation week a gateway to persistent alcohol use in university students? A preliminary investigation. J Stud Alcohol Drugs 2015; 76: 204-11.

16. Rimstad SLS, Selbekk AS, Robertson IE. Fadderuken og alkohol - unntakstilstand eller etablering av nye alkoholvaner? Rapport 2/2011. Stavanger: Kompetansesenter rus - region vest Stavanger. Rogaland A-senter, 2011.

17. Stålesen E. Hvordan opplever studenter ved Universitetet i Agder forholdet til alkohol i fadderuken? Om fester, relasjoner og overskridelser. Masteravhandling. Kristiansand: Institutt for psykososial helse, Universitetet i Agder, 2015.

18. Mellingsæter H. Skoleåret kan bli endret - nytt utvalg skal se på omorganisering. Aftenposten. 17.6.2016. http://www.aftenposten.no/norge/ Skolearet-kan-bli-endret---nytt-utvalg-skal-sepa-omorganisering-478751b.html (14.2.2017).

Mottatt 14.2. 2017, første revisjon innsendt 6.4. 2017, godkjent 18.4. 2017. Redaktør: Inge Rasmus Groote. 